\title{
Innovating at the margins: the System of Rice Intensification in India and transformative social innovation
}

\author{
Shambu C. Prasad ${ }^{1}$
}

ABSTRACT. I explore transformative social innovation in agriculture through a particular case of agroecological innovation, the System of Rice Intensification (SRI) in India. Insights from social innovation theory that emphasize the roles of social movements and the reengagement of vulnerable populations in societal transformation can help reinstate the missing "social" dimension in current discourses on innovation in India. India has a rich and vibrant tradition of social innovation wherein vulnerable communities have engaged in collective experimentation. This is often missed in official or formal accounts. Social innovations such as SRI can help recreate these possibilities for change from outside the mainstream due to newer opportunities that networks present in the twentyfirst century. I show how local and international networks led by Civil Society Organizations have reinterpreted and reconstructed game-changing macrotrends in agriculture. This has enabled the articulation and translation of an alternative paradigm for sustainable transitions within agriculture from outside formal research channels. These social innovations, however, encounter stiff opposition from established actors in agricultural research systems. Newer heterogeneous networks, as witnessed in SRI, provide opportunities for researchers within hierarchical research systems to explore, experiment, and create newer norms of engagement with Civil Society Organizations and farmers. I emphasize valuing and embedding diversity of practices and institutions at an early stage to enable systems to be more resilient and adaptable in sustainable transitions.

Key Words: civil society; innovation networks; social innovation theory; System of Rice Intensification

\section{INTRODUCTION}

The complex socioeconomic and ecological challenges faced by the world today require creating newer relationships and newer ways of thinking about social innovations. As a framework that has evolved in the West and industrial nations in response to global crises, Transformative Social Innovation Theory, or TRANSIT, has highlighted the potential of social innovations in enabling transformative change by challenging, adjusting, and/or providing alternatives to the dominant systems and institutions in society (Kemp et al. 2015).

TRANSIT examines processes through which social innovation contributes to societal transformation by drawing from and linking research on social innovation, sustainable transitions, and social movements. Societal transformation is seen as the result of "coevolutionary" interactions among ("between" is just for two parties; you refer to many more) game-changers (such as the economic crisis), narratives of change (e.g., "a new economy"), system innovations (e.g., welfare system reform), and social innovations (e.g., new design practices) (Avelino et al. 2014).

I explore and extend TRANSIT analysis in a developing country and agrarian context through the case study of an agroecological innovation, the System of Rice Intensification (SRI), in India. TRANSIT, I suggest, helps better articulate and position alternative "narratives of change" that can open up, and position, discussions on social innovations for their potential transformatory role. How could this be in the Indian context wherein the world's largest farming community facing agrarian distress is seeking to rethink agrarian futures? Would reframing social innovation within narratives of social movements create opportunities for newer narratives of change that can empower vulnerable communities by focusing on their adaptive capacities and resilience? Can TRANSIT's focus on game-changers help in reframing the dominant productionist narratives (Segal et al. 2015) to those on securing sustainable food sovereignty?
Societies like India wherein a large body of indigenous knowledge and its practitioners coexist with modern scientific knowledge often face challenges in creating knowledge dialogues due to institutional hierarchies and rigidities. "Institutional entrepreneurs" (Moore and Westley 2011) who could change systems and enable system-wide innovations do not easily emerge in such contexts. What would be the role of Civil Society Organizations (CSOs) in such contexts as intermediaries and in creating spaces for "creative dissenters" in articulating alternative narratives of change? I seek to address these questions through the SRI case in India.

I begin with an overview of discussions on innovation in India. I first show how social innovation is underplayed or missing in current narratives on innovation policies in India that are excessively focused on techno-economic innovations. Drawing from research on social movements and social innovation (Mulgan 2006, Murray et al. 2010, Westley and Antadze 2010, Westley 2013, Westley et al. 2013, Avelino et al. 2014, Smith 2014), I propose an alternative narrative of change drawing from Gandhi's experiments on a science by people during India's freedom struggle.

Social innovations, I show, have often been incubated by a vibrant civil society in India that has gone beyond state and market failure to experiment with and articulate alternative and sustainable visions of development (Shrivastava and Kothari 2012). Applying TRANSIT frames of linking social innovation to social movements helps us better appreciate this tradition of innovations by vulnerable communities. Thus, although SRI originated as a grassroots innovation in Madagascar, I suggest that it is because of this rich, yet forgotten tradition of social innovation and movements that India has become the institutional home for diverse experiments and innovations on SRI.

In the section Agrarian Crisis, Game-changers, I show how macrophenomena are interpreted, (re)constructed, contested, and dealt with by vulnerable people and CSOs working on 
alternative agricultural imaginations amidst a large-scale farming crisis in India. The evolution of SRI in India is traced as a dynamic and diverse response shaped by a coalition of actors articulating alternative "narratives of change" as a transformatory sociotechnical innovation. I show how ideas of "learning alliances " (Lundy et al. 2005, Douthwaite et al. 2009) and innovation platforms (Kilelu et al. 2013) have played an important part in enabling sustainable transition.

Unlike strong institutional entrepreneurs acting in European and North American contexts, innovators in developing countries often encounter significant resistance in (re)orienting systems toward sustainable transitions. Civil Society Organizations play an important role both in enabling and embedding the diversity of social innovations in developing-country contexts. They create and use innovation networks to foster and enable "creative dissent" (Prasad 2014a, 2015) by potential change-makers. I use empirical data and insights from a long-term study on innovation and SRI, as well as my participation in several policy dialogues in trying to change agricultural narratives of change in India. The focus is on interpreting innovation processes by multiple actors on SRI.

\section{SOCIAL INNOVATION AND SOCIAL MOVEMENTS IN INDIA}

India's rise as a twenty-first century innovation superpower has been celebrated with new phrases such as "frugal," "reverse," and Jugaad (the Indian equivalent of Bricolage) entering the innovation management lexicon (Birtchnell 2011, Kumar and Puranam 2012, Govindarajan and Trimble 2013). However, social innovation and sustainability in public policies is conspicuous by their absence in discussions of India's Science, Technology and Innovation Policy (GoI 2013) or the more recent mission on innovation and entrepreneurship (GoI 2015). Policy documents in this linear model of innovation privilege the know-all technical expert who would deliver solutions to the "lay" citizen seen as lacking knowledge. Public policies tend to delegate civil society's role to the bottom of the innovation chain (Prasad 2005) in seeking to disseminate innovation rather than regarding other actors as partners in a search for newer models of "inclusive inclusion" (Bound and Thornton 2012). India's lesser-known innovation networks, I suggest, have, however, demonstrated the capacity and resilience of vulnerable people in bringing transformative social innovation.

The Indian national movement led by M. K. Gandhi, who envisioned an alternative narrative of change and development as part of India's political struggle for freedom, could be seen as a precursor to social innovation in India. The rejuvenation of the handmade cloth industry (khadi) that empowered millions during the Freedom Movement involved large-scale collective experimentation. Social innovations were seen as a space for civil society in areas that required "tender nursing," which neither the state nor the market could institutionally provide for.

Gandhi viewed his own ashrams (religious hermitages), traditionally associated with spaces for spiritual and religious practice, as laboratories where technical experiments in cotton growing, processing, spinning and weaving, rural industries, and sanitation went along with transformative social innovations. More men became engaged in spinning, an activity otherwise long seen as women's domain. These social movements invited innovations through contests and awards such as the Rs. 1 lakh (7700 pounds) prize offered for an improved spinning wheel in 1929 by the All India Spinners Association, which had strong social design criteria and principles for innovators to adhere to. The contest eventually had no winners, but the award and discussions between the short-listed entries and Gandhi and his coworkers indicate the true value in creating an atmosphere for social change through citizen's participation (Prasad 2002:112129).

Several CSOs in independent India drew from Gandhian ideals of social innovation. Prominent among these were Baba Amte's Maharogi Sewa Samiti (founded in 1949), which transformed the lives of lepers, Manibhai Desai's Bharatiya Agro Industries Foundation in 1967, which pioneered innovations in animal husbandry, and Ela Bhatt's Self Employed Women's Association in 1972, which pioneered women's empowerment by organizing the poor. The space for social innovation had a surge in the late 1970s and early 1980s, with many qualified scientists and technologists exploring alternative scientific futures for India's poor as part of a vision of science and technology for rural transformation (Jain 2002, Prasad 2005, Bhaduri and Kumar 2011, Gupta 2012).

Social innovation movements today are recognized for their role in envisioning innovation processes that include local communities in terms of knowledge and processes, and in the framing of a collaborative innovation activity (Smith, Fressoli, and Thomas 2014). SRI is one such movement from below led by CSOs in recent times that has enabled articulating a transformative social innovation to the ongoing large-scale agrarian crisis in India.

\section{AGRARIAN CRISIS, GAME-CHANGERS, AND THE SUSTAINABILITY IMPERATIVE}

Agriculture in India is beset with paradoxes. India leads world production of milk and buffalo meat, is second in wheat, sugar, fruits, and vegetables, and paradoxically also leads the world in number of farm suicides. The world's largest farming community has witnessed farmer suicides at unprecedented scales in the twenty-first century and is part of a long-standing agrarian crisis (Mishra 2014). While productivity has increased, farm incomes have stagnated or declined. High dependence on external inputs - seeds, fertilizer, and irrigation water, coupled with increased indebtedness - has meant that Indian farmers are experiencing a loss of agency, "agricultural individualization," and "knowledge dissonance" (Vasavi 2012), and deskilling (Stone 2007). The Indian farmer is more vulnerable to game-changing trends that include increased costs, declining and fluctuating commodity prices, and high variability and unpredictability of weather. Drought is now a recurring phenomenon, with monsoon patterns commonly shifting by a few weeks or even months. (At the end of the 2015 season, half of India's districts had deficit rainfall.)

Globally, agriculture is on an unsustainable track with a high and ever-increasing ecological footprint. Application of synthetic fertilizers as one of the fastest growing sources of greenhouse gas emissions is one such game-changing trend. Agriculture accounts for $70 \%$ of water use withdrawals and $86 \%$ of consumptive use globally (McIntyre et al. 2009:279). Nearly 2 billion hectares and 2.6 billion people have been affected by significant land degradation resulting from agricultural practices associated with 
the Green Revolution (Nierenberg 2013, Smith, Bustamante, et al. 2014). Farmers groups, especially those of, or for, small landholders, have little bargaining power in global agricultural value chains (Van der Ploeg 2014).

These global trends are compounded by game-changing trends that are specific to India. The annual extraction of groundwater in India ( 210 billion cubic meters) is the highest in the world. Poor quality and shortages of groundwater are experienced in more than $60 \%$ of districts in India (Shah 2013). Fertilizer subsidies in India not only cost the Indian exchequer vast amounts of money but are skewed with greater use of urea and nitrogen to benefit irrigated areas and a few crops, with soil quality consequently deteriorating in the longer run (Rupela and Gopikrishna 2011). Macrotrends or landscape developments can lead to newer narratives of change for social innovation (Elzen et al. 2012, Avelino et al. 2014). Social movements for agroecology have articulated the sustainability imperative and the need to move away from existing Green Revolution-based technologies and food systems. Agroecology-defined as "the application of ecological concepts and principles to the design and management of sustainable agro-ecosystems"- draws from ongoing food sovereignty and ecology movements, and presents an alternative narrative of change and response to these macrotrends on climate change and agriculture. Agroecological methods provide greater environmental sustainability and enhance the resilience of farmers by reducing their dependence on costly and sometimes difficult-to-access chemical inputs. There is increased overall productivity through a diverse range of agricultural products and environmental services, and reduced risks of crop failure (Wezel et al. 2009, Silici 2014, Tittonell 2014).

However, existing institutions and research practices hinder the greater expression of local innovations that have demonstrated this potential for societal transformation. Vanloqueren and Baret (2009) have shown how overall organization of research systems favors dominant genetic engineering research rather than agroecological methods. This is not necessarily due to any inherent merit of the former or demerits of the latter but due to technological lock-ins in agricultural research. In agriculture, a sustainable transition in agriculture research would require more than increased funding or expenditure but also attention to the larger framework and power that influences S\&T choices. Despite support from broad-based social movements, CSOs, and policymakers within various countries, there has been little shift in international thinking on agricultural futures (Feldman and Biggs 2012). These issues of power relations, especially in agricultural research, I suggest, hinder system innovations within the TRANSIT framework. In the case on SRI, I show how these macrodevelopments have been perceived by CSOs to contribute to "the collective understanding of the persistency and unsustainability of the dominant discourses and practices to encourage a diffusion of alternatives" (Avelino et al. 2014:19) through networks and creating spaces for creative dissent.

\section{SPREAD OF THE SYSTEM OF RICE INTENSIFICATION IN INDIA: SOCIAL INNOVATION AND VULNERABLE FARMERS}

The System of Rice Intensification is an agroecological innovation that does not depend on conventional Green Revolution strategies of intensification through introduction of improved genotypes for productivity enhancement-genotypes that are themselves dependent on the application of purchased agrochemical inputs. Instead, through changes in the management of rice plants, soil, water, and nutrients, with reduced use of material inputs, SRI principles enable the emergence of more productive and robust phenotypes. These principles translate into a set of practices that differ from conventional rice cultivation techniques and involve transplantation of young seedlings, widely spaced, in unflooded but moist soil conditions, and involve the greater use of organic matter in soil, and a hand or motorized weeder for weed control which also aerates the soil surface. As an innovation, SRI emerged through constant experimentation with farmers by Fr Henri De Laulanie in Madagascar in the 1970s and 1980s, and later through the Association Tefy Saina that he founded in 1990.

The System of Rice Intensification was unknown to the rest of the world until 1999, and it was through the institutional entrepreneurship of the Cornell International Institute of Food Agriculture and Development (CIIFAD) and its then director, Norman Uphoff, that treated the innovation as "open source" from the outset, thereby ensuring free access by farmers and researchers to the new ideas and opportunities. As SRI practices involved no miracle seed or herbicides for improving productivity, resource-poor farmers, first in Madagascar and later in other parts of the world, were encouraged to draw on their own potential for experimentation instead of expecting and letting commercial interests drive and dominate agricultural innovation. The rapid growth of the Internet, through e-mail and websites, and more recently social media, helped the spread of SRI across the world with continuous adaptation. An estimated 10 million farmers across 50 countries have experimented with many or all SRI principles on more than 4 million hectares (Kassam et al. 2011, Uphoff et al. 2015). Most of the spread of SRI has been from five Asian countries - China, India, Vietnam, Indonesia, and Cambodia.

The System of Rice Intensification presented an alternative "narrative of change" to the strategies and narratives of yield enhancement of the International Rice Research Institute that involved enormous investments in developing a radical new plant type or genetically modifying rice to have a $\mathrm{C} 4$ photosynthetic pathway instead of C3. The high yields reported from SRI fields, exceeding what was seen as the biological maximum, led to "ricewars" and scientific controversies (Prasad and Basu 2005, Berkhout and Glover 2011, Glover 2014) from 2004 (the International Year of Rice) onward, with critics even dismissing SRI results derisively as "Agronomic UFOs" (Sinclair and Cassman 2004). The international controversy had an effect on Indian researchers who were largely reluctant to carry out research trials on SRI. India since has been an important site for contestations, controversies, dialogues, alliances, and experimentation. The System of Rice Intensification has been shaped by multiple actors in complex and diverse relations of formal researchers in the agricultural establishment and CSOs and their networks (Prasad 2006). Table 1 summarizes this process, and highlights five broad phases using categories of subprocesses of socialecological transformation processes (Moore et al. 2014)

India started later than China and Indonesia on SRI research, but SRI tapped diverse routes for knowledge creation and 
Table 1. Complex evolution of System of Rice Intensification (SRI) in India (1999-2015).

\begin{tabular}{|c|c|c|c|c|}
\hline Phase & Period & Characteristic of social innovation & Key events & Key actors \\
\hline 1 & $1999-2003$ & $\begin{array}{l}\text { Early experimentation by civil } \\
\text { society and researchers in South } \\
\text { India, drought as a trigger }\end{array}$ & $\begin{array}{l}\text { Civil Society Organizations (CSOs) access innovation } \\
\text { through LEISA article 1999, India represented in } \\
\text { International SRI conference in China (2002), modest } \\
\text { results }\end{array}$ & $\begin{array}{l}\text { Organic farmer groups } \\
\text { in South India, } \\
\text { researchers in Tamil } \\
\text { Nadu and Andhra } \\
\text { Pradesh }\end{array}$ \\
\hline 2 & $2004-2006$ & $\begin{array}{l}\text { Sensemaking and envisioning: } \\
\text { building the network and } \\
\text { innovation platform }\end{array}$ & $\begin{array}{l}\text { Indian researchers respond to SRI "Rice Wars," World } \\
\text { Wide Fund (WWF) organizes multistakeholder national } \\
\text { symposium } 2006\end{array}$ & $\begin{array}{l}\text { WWF, PRADAN, state } \\
\text { universities }\end{array}$ \\
\hline 3 & $2007-2009$ & $\begin{array}{l}\text { Gathering momentum, selecting, } \\
\text { learning adopting diversified SRI, } \\
\text { navigating transition }\end{array}$ & $\begin{array}{l}\text { National symposiums in different locations (2007-2008), } \\
\text { state-level alliances ( } 2007 \text { onwards) }\end{array}$ & $\begin{array}{l}\text { Sir Dorabji Tata Trust } \\
\text { and partners }\end{array}$ \\
\hline 4 & $2010-2014$ & $\begin{array}{l}\text { Navigating transition and } \\
\text { attempts to institutionalize }\end{array}$ & $\begin{array}{l}\text { Policy dialogues ( } 2009 \text { onwards), extensive } \\
\text { experimentation in other crops, rural development } \\
\text { department newer leader }\end{array}$ & $\begin{array}{l}\text { National Consortium on } \\
\text { SRI and CSOs, rural } \\
\text { livelihood missions }\end{array}$ \\
\hline 5 & 2014 & $\begin{array}{l}\text { Rethinking and reperceiving } \\
\text { system }\end{array}$ & $\begin{array}{l}\text { Open system with no "strategic agency" for cross-scale } \\
\text { interactions }\end{array}$ & $\begin{array}{l}\text { National Consortium on } \\
\text { SRI and livelihood } \\
\text { missions }\end{array}$ \\
\hline
\end{tabular}

dissemination. An ecological crisis, drought in 2002-03, spurred research on SRI in South India, with state agricultural universities in Tamil Nadu and Andhra Pradesh taking leads. Simultaneously, CSO networks, particularly on organic farming, popularized SRI principles, enabling reinterpretation of the debates and controversies on SRI that were excessively focused on super-yields through SRI. They pointed instead to its potential for resilience and adaptation for small farmers facing climate stress (Prasad and Basu 2005, Prasad 2006).

A new chapter in Indian SRI emerged due to the active involvement of a CSO envisioning and positioning an alternative narrative of SRI through "institutional entrepreneurship" (Moore and Westley 2011). The World Wide Fund (WWF) in India, based at the International Crop Research Institute of SemiArid Tropics (ICRISAT), was attracted to SRI due to its watersaving potential, and incorporated it in the ongoing "Dialogue Project on Water Food and Environment" conducted between WWF and ICRISAT. The WWF project funded evaluation trials by researchers from the Andhra Pradesh state agricultural university, and collaborative research by the Directorate of Rice Research and ICRISAT researchers that was conducted on farmers' fields, which included dialogue with farmers and CSOs on their work.

These dialogues constituted "innovation platforms" (Kilelu et al. 2013, Klerkx et al. 2013) that broke the pattern of "reluctant partnership" (between researchers and farmers) generally witnessed in Indian agriculture (Farrington and Bebbington 1993). Researchers, policy-makers, CSOs, and farmers shared and exchanged ideas on agricultural futures through SRI experimentation and evaluation that also saw the creation of novel innovation spaces such as the National Symposium on SRI in 2006 at Hyderabad (followed by similar events in Agartala in northeast India in 2007 and Coimbatore in Tamil Nadu in 2008).

In a third phase, there was a deepening of these knowledge spaces through several nodes that repeated these institutional experiments through state-level platforms and learning alliances. The System of Rice Intensification spread as a knowledge commons (Prasad and Sen 2010) through e-groups with actors exchanging notes across states through learning alliances (Prasad et al. 2007, Prasad 2009). The changes in location and actors not only extended SRI as an innovation but also brought newer meanings and dimensions to SRI. The inconsistent SRI uptake in the state of Andhra Pradesh, despite successful trials and early farmer experimentation, pointed to the need for changed behavior by farmers and laborers, both individually and collectively. Farmers with larger landholdings in South India, especially Andhra Pradesh, experienced the need for greater managerial time in organizing and supervising laborers to ensure timely operations in SRI, and some began "disadoption." With support to CSOs through an Indian donor, the Sir Dorabji Tata Trust, SRI spread in many of the poorer rain-fed regions of Bihar, Odisha, Jharkhand, and Chhattisgarh, as well as the mountain states of Himachal Pradesh and Uttarakhand. The surprising spread of SRI away from irrigated Green Revolution areas to rain-fed areas, and from farmers with larger landholdings to farmers with small and marginal landholdings also meant a shift toward household or local food security, with water management (and saving) not the primary concern.

Intensive policy dialogues for SRI scaling up characterized the fourth phase of SRI. This happened at both the national and state levels and even a policy by the Department of Agriculture that included SRI as part of the National Food Security Mission in 133 food-insecure districts. An informal network, the National Consortium on SRI (NCS), that built on the work of WWF and Sir Dorabji Tata Trust's partners, took the discussions to the Indian research establishment, which was still reluctant to institutionalize ongoing SRI experiments as a regular agricultural practice. Mainstreaming the social innovation to becoming a system innovation, the NCS pointed out, required investments and institutional changes in extension systems. Local communities that were neither public nor private agents took a lead in disseminating the innovation. This need to invest in human and institutional capacities of communities as experimenters and transmitters of knowledge was brought out strongly by the experiments of various CSOs. They, however, found little 
acceptance in policy circles, with SRI seen merely as a technical innovation that was added as an option in existing institutional arrangements. Thus, when SRI was introduced in the National Food Security Mission by the government, it was reduced to the supply of weeders or hybrid seeds within the dominant input supply paradigm of agricultural extension.

The diversity of practices enabled unanticipated policy innovations. The Rural Development Ministry's National Rural Livelihood Mission and its state agencies saw in SRI an opportunity for its empowered community resource persons from women's self-help groups. The poverty reduction and livelihoods focus of the Livelihood Mission was in contrast to that of the Departments of Agriculture that worked with and supported large or progressive male farmers. The ongoing phase of SRI is one where in the absence of a "strategic agency," cross-scale changes in complex systems do not occur easily (Moore and Westley 2010). The System of Rice Intensification today has features of an open-system wherein an actor could seize the opportunity for transformative change by making these changes across scales in the system. Left to itself, the agricultural establishment is, however, unlikely to lead this change due to institutional rigidities. From tentative beginnings and experiments in early 2000, India today is a world leader in SRI, both in terms of publication outputs and number of experimenting farmers. Indian farmers have led the System of Crop Intensification movement, an extension of SRI principles to other crops, much before researchers have conducted any onstation trials. The NCS worked with the Indian Agricultural Research Institute to set up and conduct on-station trials on the System of Wheat Intensification, with an interesting reversal of roles where civil society brought in farmers and their expertise to the research centers to conduct the trials (Dhar et al. 2015).

Indigenous varieties of rice that fell out of favor during the Green Revolution have responded well to SRI management, enhancing the scope for farmers to focus on varieties that improve household nutritional security in many parts of malnourished India. Indian researchers lead in total number of journal articles, books, and other publications (Prasad and Barah 2013, Thiyagarajan and Gujja 2013, Prasad 2014b, Abraham et al. 2014, Uphoff et al. 2015). The reemergence of drought, and newer narratives on collective action and adaptations by farmers (Sen 2015), can lead to rethinking system innovation in and through SRI. In this, CSOs and networks are likely to play an important role.

\section{INNOVATION SPACES AND NETWORKS IN SYSTEM INNOVATION}

The overview of evolution of SRI in India over a decade reflects some features of innovation undergoing system transitions. Game-changing trends such as climate change, soil degradation, and farmers' suicides require responses and strategies that build and enhance communities' capacities to experiment and change. Conventional research focused on measuring diffusion of innovation and adoption rates of SRI as a technology treats communities and farmers as static entities and does not account for the adaptations by different users who constantly shape the innovation through experimentation. The System of Rice Intensification in India is not one agroecological innovation replacing a Green Revolution technology but an opportunity that fits differently in different agroecological and institutional contexts. Actors, farmers, and CSOs understand and interpret
SRI differently. Embedding this diversity in policy design is important but poses challenges in the way that the social innovation is framed. A dominant framing based on metaphors of spread of mobile phones is that SRI has not scaled or spread fast enough. However, from a social innovation point of view, the creation of new innovation spaces and networks that can enable sustainable transitions and reengage vulnerable communities is as important as policy uptake or rapid spread of a technology.

Innovation spaces provide opportunities for actors to learn both individually and collectively (Prasad 2009). The System of Rice Intensification has seen the emergence of a heterogeneous "support network" with embedding different institutional entrepreneurs that transcends conventional agricultural networks (Basu and Leewis 2012). The National Symposia (2006-08) and state-level "learning alliances" and workshops enabled a few scientists to work outside their disciplinary (and crop) biases and integrate better with other actors. The open-source collaborative architecture enabled emergence of a new knowledge commons in agriculture (Prasad and Sen 2010). This has had diverse forms such as e-groups and regional networks, joint participation in subpanels at mainstream rice conferences, wide sharing of newer manuals, videos and PowerPoint presentations made in different forums, and specialized Facebook pages on equipment. The diversity of these networks induces transformation in knowledge systems and could avoid the kind of domination by researchers in innovation platforms witnessed elsewhere (Schut et al. 2015).

New knowledge often resides in the interaction of diverse actors facilitated through networks aligned, but not necessarily in agreement, around common interests. The Cornell University support capacity (initially CIIFAD but now SRI-Rice within Cornell's College of Agriculture's International Programs) and Norman Uphoff, in particular, have provided useful support to young researchers in the informal transnational networks by serving as an informal peer group and building research capacities of researchers from developing countries by providing pro bono editorial support and advice. Researchers have benefited from the specialized documentation service on the SRI-Rice website (http://sri.cals.cornell.edu/research/index.html), which provides access to all SRI articles in a single location made possible through coordination of many informal networks and capturing local research that often escapes international databases.

Networks have had a silent, often invisible empowering role for individuals within established and hierarchical organizations. They have encouraged agricultural researchers to be "creative dissenters" by providing space for conversations across the boundaries of their own disciplines (Prasad et al. 2012, Prasad 2014a). Power relations are altered not only through active dissent by CSOs and farmers groups. It often requires creative dissenters within the scientific establishment who have the ability to listen to nonresearch actors and translate ideas of paradigm change and sustainability to agricultural researchers. Scientists like the late Sanghi and Rupela were part of several multiactor networks that had flat organizational forms. They played important roles in empowering nonresearch actors (CSOs, farmers, and their organizations and networks) toward pushing for an alternative discourse in policy circles on sustainable transitions in agriculture. Innovation needs creative dissent, and networks provide opportunities for expressing and strengthening these capacities (Prasad 2015). 


\section{CONCLUSIONS}

Twenty-first century agriculture in India has been known for farm suicides, deskilling, and agricultural individualization. Coincidentally, the spread of SRI offers an alternative narrative of farmers reclaiming control over their livelihoods through experimentation, collective action, adaptation, and innovation. While not all farmers have continued with the package of practices recommended for SRI, and as conventionally understood even disadopted, viewing SRI from the lens of system transformation (Westley and Antadze 2010) allows for reworking the relationship between the social innovation (SRI) and the resilience and reengagement of vulnerable populations. While the imperative of change and sustainability is evident from many of the gamechanging trends in agriculture, there is a need for public policies to rethink how to manage sustainable transitions.

Designing policies on largely technical parameters such as yields or productivity is not likely to support transformative change unless the social aspects of the innovation that enhance resilience and the adaptive capacity of vulnerable communities are taken into account. Recent literature on social innovation and social movements indicate some contours of such a shift. The System of Rice Intensification in India can be explained through existing frameworks of social innovation (Moore et al. 2014), highlighting "triggers" like drought or ecological crisis for change, or "preparing for change" through networks and creative dissenters.

The transition to sustainability, however, is not navigated as easily because current frameworks perhaps do not adequately account for power relations and knowledge hierarchies in developing country contexts that resist change. The persistence of the linear or pipeline model of innovation deters alternatives that emerge outside the agricultural research establishment, and sustainable transitions in agriculture might require creative responses. In managing a transition, researchers need to go beyond simply building their organizations, or their academic networks, and should concentrate on building capacity outside their organizations (Wei-Skillern and Marciano 2008). The investment in newer institutional forms, such as common innovation platforms and innovation networks and learning alliances, should be an important aspect of shifts toward sustainable intensification of food systems (Klerkx et al. 2010, Schut et al. 2015).

As an innovation, SRI relates well to the idea of social innovation as one that encourages collective experimentation, as expressed in the EU's report on "taking knowledge seriously" (Felt and Wynne 2007), as well as in the Indian tradition of innovating at the margins, following Gandhi. I have shown how game-changers such as the agrarian and ecological crisis can open up spaces for social innovations such as SRI. These innovations have the potential for societal transformation if, using TRANSIT's framework, greater attention is given to narratives of change. In the context of Indian agriculture, social innovations are strengthened by CSOs and by their innovation networks that not only enable the reengagement of vulnerable populations but also provide opportunities for creative dissent. Institutionalization of a new trajectory as a phase in TRANSIT framing does not easily happen and would need greater space for dissent within institutions. The Indian case also highlights the need to embed diversity in ongoing discussions on sustainable transitions.
Responses to this article can be read online at: http://www.ecologyandsociety.org/issues/responses. $\mathrm{php} / 8718$

\section{Acknowledgments:}

I acknowledge the contribution of the Knowledge In Civil Society network for insights on social movements in India, the Wageningen University team of researchers for insights and collaborations from the project "SRI as a socio-technical movement in India" and SRI RIce, Cornell University for discussions and material on innovation networks on SRI. I thank the DRIFT team and TRANSITnetworks for useful leads and theoretical insights at the Rotterdam conference in September 2014 , and the reviewers for their useful comments and suggestions. Usual disclaimers apply.

\section{LITERATURE CITED}

Abraham, B., H. Araya, T. Berhe, S. Edwards, B. Gujja, et al. 2014. The System of Crop Intensification: reports from the field on improving agricultural production, food security, and resilience to climate change for multiple crops. Agriculture and Food Security 3(1):4. http://dx.doi.org/10.1186/2048-7010-3-4

Avelino, F., J. Wittmayer, A. Haxeltine, R. Kemp, T. O'Riordan, P. Weaver, D. Loorbach, and J. Rotmans. 2014. Game changers and transformative social innovation. The case of the economic crisis and the new economy. TRANSIT working paper. DRIFT, Rotterdam, Netherlands. [online] URL: http://www.

transitsocialinnovation.eu/content/original/TRANSIT $\% 20$ outputs $/ 91 \%$ 20Gamechangers_TSI_Avelino_etal_TRANSIT_workingpaper_2014. pdf

Basu, S., and C. Leeuwis. 2012. Understanding the rapid spread of System of Rice Intensification (SRI) in Andhra Pradesh: exploring the building of support networks and media representation. Agricultural Systems 111:34-44. http://dx.doi. org/10.1016/j.agsy.2012.04.005

Berkhout, E., and D. Glover. 2011. The evolution of the System of Rice Intensification as a socio-technical phenomenon: a report to the Bill \& Melinda Gates Foundation. Wageningen University and Research Centre, Wageningen, Netherlands. [online] URL: http://dx.doi.org/10.2139/ssrn.1922760

Bhaduri, S., and H. Kumar. 2011. Extrinsic and intrinsic motivations to innovate: tracing the motivation of 'grassroot' innovators in India. Mind \& Society 10(1):27-55. http://dx. doi. org/10.1007/s11299-010-0081-2

Birtchnell, T. 2011. Jugaad as systemic risk and disruptive innovation in India. Contemporary South Asia 19(4):357-372. http://dx.doi.org/10.1080/09584935.2011.569702

Bound, K., and I. W. Thornton. 2012. Our Frugal future: lessons from India's innovation system. Nesta, London, UK.

Dhar, S., B. C. Barah, A. K. Vyas, and N. Uphoff. 2015. Comparing System of Wheat Intensification (SWI) with standard recommended practices in the north-western plain zone of India. Archives of Agronomy and Soil Science 1:1-13. 
Douthwaite, B., N. Beaulieu, M. Lundy, and D. Peters. 2009. Understanding how participatory approaches foster innovation. International Journal of Agricultural Sustainability 7:42-60. http://dx.doi.org/10.3763/ijas.2009.0339

Elzen, B., M. Barbier, M. Cerf, and J. Grin. 2012. Stimulating transitions towards sustainable farming systems. Pages $431-455$ in I. Darnhofer, D. Gibbon, and B. Dedieu, editors. Farming systems research into the 21st century: the new dynamic. Springer, Netherlands. http://dx.doi.org/10.1007/978-94-007-4503-2 19

Farrington, J., and A. Bebbington. 1993. Reluctant partners: nongovernmental organizations, the state and sustainable agricultural development. Psychology Press, London, UK.

Feldman, S., and S. Biggs. 2012. International shifts in agricultural debates and practice: an historical view of analyses of global agriculture. Pages 107-161 in W. B. Campbell and S. L. Ortiz, editors. Integrating agriculture, conservation and ecotourism: societal influences. Vol. 2. Springer, Dordrecht, Netherlands. http://dx.doi.org/10.1007/978-94-007-4485-1 2

Felt, U., and B. Wynne. 2007. Taking European knowledge society seriously. Directorate-General for Research, European Commission, Luxembourg. [online] URL: http://www.synbioproject.org/ process/assets/files/6452/_draft/european-knowledge-society_en. pdf

Glover, D. 2014. Of yield gaps and yield ceilings: making plants grow in particular places. Geoforum 53:184-194. http://dx.doi. org/10.1016/j.geoforum.2013.06.001

Government of India (GoI). 2013. Science, technology and innovation policy 2013. New Delhi, India.

Government of India (GoI). 2015. Report of the Expert Committee on Innovation and Entrepreneurship. NITI Aayog, New Delhi, India. [online] URL: http://niti.gov.in/writereaddata/ files/new initiatives/report-of-the-expert-committee.pdf

Govindarajan, V., and C. Trimble. 2013. Reverse innovation: create far from home, win everywhere. Harvard Business Press, Cambridge, Massachusetts, USA.

Gupta, A. K. 2012. Innovations for the poor by the poor. International Journal of Technological Learning, Innovation and Development 5(1):28-39. http://dx.doi.org/10.1504/IJTLID.2012.044875

Jain, A. 2002. Networks of science and technology in India: the elite and the subaltern streams. AI and Society 16(1-2):4-20.

Kassam, A., W. Stoop, and N. Uphoff. 2011. Review of SRI modifications in rice crop and water management and research issues for making further improvements in agricultural and water productivity. Paddy and Water Environment 9(1):163-180. http:// dx.doi.org/10.1007/s10333-011-0259-1

Kemp, R., L. Zuijderwijk, P. Weaver, G. Seyfang, F. Avelino, F. T. Strasser, L. Becerra, J. Backhaus, and S. Ruijsink. 2015. Doing things differently: exploring transformative social innovation and its practical challenges. TRANSIT Brief 1. [online] URL: http:// www.transitsocialinnovation.eu/content/original/Book $\% 20$ covers/ Local $\% 20$ PDFs $/ 182 \% 20$ TRANSIT $\% 20$ brief $\% 20$ no $\% 201$.pdf

Kilelu, C. W., L. Klerkx and C. Leeuwis. 2013. Unravelling the role of innovation platforms in supporting co-evolution of innovation: contributions and tensions in a smallholder dairy development programme. Agricultural Systems 118:65-77. http:// dx.doi.org/10.1016/j.agsy.2013.03.003

Klerkx, L., N. Aarts, and C. Leeuwis. 2010. Adaptive management in agricultural innovation systems: the interactions between innovation networks and their environment. Agricultural Systems 103(6):390-400. http://dx.doi.org/10.1016/j.agsy.2010.03.012

Klerkx, L., S. Adjei-Nsiah, R. Adu-Acheampong, A. Saïdou, E. Zannou, L. Soumano, O. Sakyi-Dawson, A. van Paassen, and S. Nederlof. 2013. Looking at agricultural innovation platforms through an innovation champion lens. An analysis of three cases in West Africa. Outlook on Agriculture 42:185-192. http://dx.doi. org/10.5367/oa.2013.0137

Kumar, N., and P. Puranam. 2012. India inside: the emerging innovation challenge to the West. Harvard Business Press, Cambridge, Massachusetts, USA.

Lundy, M., M. V. Gottret, and J. Ashby. 2005. Learning alliances: an approach for building multi-stakeholder innovation systems. ILAC Brief No. 8. Bioversity, Rome, Italy.

McIntyre, B. D., H. R. Herren, J. Wakhungu, and R. T. Watson, editors. 2009. Agriculture at a crossroads: report of the international assessment of agricultural knowledge, science, and technology, 7 vols. Island Press, Washington, D.C., USA.

Mishra, S. 2014. Farmers' suicides in India, 1995-2012: measurement and interpretation. Asia Research Centre Working Paper 62. London School of Economics and Political Science, London, UK.

Moore, M.-L., O. Tjornbo, E. Enfors, C. Knapp, J. Hodbod, J. A. Baggio, A. Norström, P. Olsson, and D. Biggs. 2014. Studying the complexity of change: toward an analytical framework for understanding deliberate social-ecological transformations. Ecology and Society 19(4):54. http://dx.doi.org/10.5751/ es-06966-190454

Moore, M. L., and F. Westley. 2011. Surmountable chasms: networks and social innovation for resilient systems. Ecology and Society 16(1):5.

Mulgan, G. 2006. The process of social innovation. Innovations 1(2):145-162. http://dx.doi.org/10.1162/itgg.2006.1.2.145

Murray, R., J. Caulier-Grice, and G. Mulgan. 2010. The open book of social innovation. National Endowment for Science, Technology and the Art. [online] URL: http://www.nesta.org.uk/ publications/open-book-social-innovation

Nierneberg, D. 2013. Agriculture: growing food and solutions. Pages 190-200 in E. Assadourian, T. Prugh, and L. Starke, editors. State of the world 2013: Is sustainability still possible? Island Press, Washington, D.C., USA. http://dx.doi.org/10.5822/978-1-61091-458-1_17

Prasad, C. S. 2002. Exploring Gandhian science: a case study of the khadi movement. Dissertation. Indian Institute of Technology, Delhi, India. [online] URL: https://www.researchgate.net/ publication/288737414_Exploring_Gandhian_Science_A_Case study of the Khadi Movement

Prasad, C. 2005. Science and technology in civil society: innovation trajectory of spirulina algal technology. Economic and Political Weekly 40:4363-4372. 
Prasad, C. S. 2006. System of Rice Intensification in India: innovation history and institutional challenges. WWF-Dialogue Project at the International Crop Research Institute for Semi-Arid Tropics, Hyderabad, India.

Prasad, C. S. 2009. Encounters, dialogues and learning alliances: the System of Rice Intensification in India. Pages 82-87 in I. Scoones, and J. Thompson, editors. Farmers first revisited: innovation for agricultural research and development. Earthscan, London, UK.

Prasad, C. S. 2014a. Creative dissent: linking vulnerability and knowledge in India. In A. Hommels, W. Bijker, and J. Messman, editors. Vulnerability in technological cultures: new directions in research and governance. MIT Press, Boston, Massachusetts, USA.

Prasad, C. S. 2014b. Uprooting rice science to building a research community: research policy challenges and prospects of SRI in India. International SRI research seminar on recent changes in rice production and rural livelihoods: new insights on SRI as a sociotechnical movement in India. [online] URL: http://www.sri-india. net/event2014/documents/presentations/Presentation 20.pdf

Prasad, C. S. 2015. Creating knowledge spaces through knowledge dialogues. Pages 44-57 in K. Suresh, C. Udayashankar, M. V. Rama Chandrudu, and M. V. Sastri, editors. Knowledge for change: essays in memory of Dr. N.K. Sanghi. WASSAN Foundation and Permanent Green, Hyderabad, India. [online] URL: http://wassan.org/sri/documents/In $\% 20$ memory $\%$ 200f $\% 20$ Dr. $\% 20$ N.K. $\% 20$ Sanghi $\% 20-\% 20$ KNOWLEDGE $\% 20$ for $\%$ 20CHANGE.pdf

Prasad, C. S., and B. C. Barah. 2013. Upscaling SRI: unpacking innovation, investments and institutions. LEISA India 15(1):1619.

Prasad, C. S., and P. K. Basu. 2005. Understanding scientific controversies: the case of the System of Rice Intensification (SRI). India' water economy: bracing up for a turbulent future. Fourth Annual IWMI-TATA Partners Meet, February 24-26, 2005, Institute of Rural Management Anand. [online] URL: https://www.researchgate.net/publication/232219323 Understanding scientific controversies the case of the System of RiceIntensification_SRI

Prasad, C. S., K. Beumer, and D. Mohanty, editors. 2007. Towards a learning alliance: System of Rice Intensification in Orissa. WWFDialogue Project at ICRISAT, Hyderabad, India.

Prasad, C. S., and D. Sen. 2010. The new commons in agriculture: lessons from the margins and SRI in India. In E. Coudel, H. Devautour, C. T. Soulard, and B. Hubert, editors. ISDA 2010, Montpellier, France. [online] URL: https://hal.archives-ouvertes. $\underline{\text { fr/hal-00521398/document }}$

Prasad, C. S., T. M. Thiyagarajan, O. P. Rupela, A. Thakur, and G. V. Ramanjaneyulu. 2012. Contesting agronomy through creative dissent: experiences from India. In J. Sumberg, and J. Thompson, editors. 2012. Contesting agronomy: agricultural research in a changing world. Routledge and Earthscan, London, UK.

Rupela, O. P., and S. R. Gopikrishna. 2011. Of soils, subsidies and survival: a report on living soils. Greenpeace India,
Bangalore, India. [online] URL: http://www.greenpeace.org/ india/Global/india/report/Living $\% 20$ soils $\% 20$ report.pdf

Schut, M., L. Klerkx, M. Sartas, D. Lamers, M. M. Campbell, I. Ogbonna, P. Kaushik, K. Atta-Krah, and C. Leeuwis. 2015. Innovation platforms: experiences with their institutional embedding in agricultural research for development. Experimental Agriculture 52:537-561. http://dx.doi.org/10.1017/ $\underline{\mathrm{s} 001447971500023 \mathrm{x}}$

Segal, R., E. Millstone, and J. Thompson. 2015. An assessment of global agricultural assessments. Resource Politics 2015. Institute of Development Studies, Sussex, September 7-9, 2015. [online] URL: https://resourcepolitics2015.files.wordpress.com/2015/08/ segal-et-al.pdf

Sen, D. 2015. How smallholder farmers in Uttarakhand reworked the System of Rice Intensification: innovations from sociotechnical interactions in fields and villages. Dissertation. Wageningen University, Netherlands. [online] URL: http://papers.ssrn.com/ sol3/papers.cfm?abstract id=2699394 http://dx.doi.org/10.2139/ $\underline{\text { ssrn.2699394 }}$

Shah, M. 2013. Water: towards a paradigm shift in the Twelfth Plan. Economic and Political Weekly 48(03):40-52.

Shrivastava, A., and A. Kothari. 2012. Churning the earth: the making of global India. Penguin, New Delhi, India.

Silici, L. 2014. Agroecology - what it is and what it has to offer. Issue Paper 14629. International Institute for Environment and Development (IIED), London, UK. http://pubs.iied.org/ pdfs/14629IIED.pdf

Sinclair, T. R., and K. G. Cassman. 2004. Agronomic UFOs. Field Crops Research 88:9-10. http://dx.doi.org/10.1016/j.fcr.2004.01.001

Smith, A. 2014. Considering social innovation from a social movement perspective. TRANSIT. [online] URL: http://www. transitsocialinnovation.eu/blog/considering-social-innovation-froma-social-movement-perspective

Smith, P., M. Bustamante, H. Ahammad, et al. 2014. Agriculture, Forestry and Other Land Use (AFOLU). In O. Edenhofer, R. Pichs-Madruga, Y. Sokona, et al., editors. Climate change 2014: mitigation of climate change. Contribution of Working Group III to the Fifth Assessment Report of the Intergovernmental Panel on Climate Change. Cambridge University Press, Cambridge, Massachusetts, USA.

Smith, A., M. Fressoli, and H. Thomas. 2014. Grassroots innovation movements: challenges and contributions. Journal of Cleaner Production 63:114-124. http://dx.doi.org/10.1016/j. jclepro.2012.12.025

Stone, G. D. 2007. Agricultural deskilling and the spread of genetically modified cotton in Warangal. Current Anthropology 48:67-103. http://dx.doi.org/10.1086/508689

Thiyagarajan, T. M., and B. Gujja. 2013. Transforming rice production with SRI: knowledge and practice. National Consortium on SRI, New Delhi, India.

Tittonell, P. 2014. Ecological intensification of agriculturesustainable by nature. Current Opinion in Environmental Sustainability 8:53-61. http://dx.doi.org/10.1016/j.cosust.2014.08.006 
Uphoff, N., V. Fasoula, A. Iswandi, A. Kassam, and A. K. Thakur. 2015. Improving the phenotypic expression of rice genotypes: rethinking "intensification" for production systems and selection practices for rice breeding. Crop Journal 3:174-189. http://dx.doi. org/10.1016/j.cj.2015.04.001

van der Ploeg, J. D. 2014. Peasant-driven agricultural growth and food sovereignty. Journal of Peasant Studies 41(6):999-1030. http://dx.doi.org/10.1080/03066150.2013.876997

Vanloqueren, G., and P. V. Baret. 2009. How agricultural research systems shape a technological regime that develops genetic engineering but locks out agroecological innovations. Research Policy 38(6):971-983. http://dx.doi.org/10.1016/j.respol.2009.02.008

Vasavi, A. R. 2012. Shadow space: suicides and the predicament of rural India. Three Essays Collective, Gurgaon, India.

Wei-Skillern, J., and S. Marciano. 2008. The networked nonprofit. Stanford Social Innovation Review 6(2):38-43.

Westley, F. 2013. Social innovation and resilience: how one enhances the other. Stanford Social Innovation Review. Summer 2013: 6-8. [online] URL: http://www.bramptonbot.com/ Summer 2013 Supplement Social Innovation and Resilience.pdf

Westley, F., and N. Antadze. 2010. Making a difference: strategies for scaling social innovation for greater impact. Innovation Journal 15(2):1-19.

Westley, F. R., O. Tjornbo, L. Schultz, P. Olsson, C. Folke, B. Crona and Ö. Bodin. 2013. A theory of transformative agency in linked social-ecological systems. Ecology and Society 18(3):27. http://dx.doi.org/10.5751/es-05072-180327

Wezel, A., S. Bellon, T. Doré, C. Francis, D. Vallod, and C. David. 2009. Agroecology as a science, a movement and a practice. A review. Agronomy for Sustainable Development 29:503-515. http:// dx.doi.org/10.1051/agro/2009004 